\title{
The Study on Cultivating Practical and Innovative Talents Taking Innovation and Entrepreneurship as the Guide_ _ Taking the Nanchang Institute of Technology as an example
}

\author{
Jiajia Fu \\ Nanchang institute of science \& technology, Nanchang, China
}

Keywords: Applied undergraduate, Innovation and entrepreneurship, Practical

\begin{abstract}
Cultivating applied innovative and entrepreneurship talents is the only way for the development of colleges and universities, this paper analyzes the current situation of innovation and entrepreneurship education in China, combining with the teaching characteristics of applied undergraduate specialty for landscape architecture in Nanchang Institute of Technology. It takes innovation and entrepreneurship as the guide to cultivate practical and innovative talents, that is, through the optimizing personnel training program, improving teachers' structure, creating teaching conditions and other effective measures, to cultivate the applied innovative and entrepreneurship talents, which provides a reference for the innovative and entrepreneurial education programs for applied undergraduate specialty in colleges and universities.
\end{abstract}

\section{Introduction}

Under the background of the rapid development in the era of knowledge economy, taking innovation and entrepreneurship as the guide and cultivating the practical and innovative talents have risen to the height of national strategy and become an important way to improve the comprehensive national strength ${ }^{[1]}$. In 2010, the ministry of education pointed out in "suggestions on promoting innovation and entrepreneurship education and independent entrepreneurship of college students": "carrying out innovation and entrepreneurship education in colleges and universities, actively encouraging college students to start their own businesses, is an important strategic measure for the education system to deeply study and practice Scientific Outlook on Development and serve the construction of an innovative country." Although many universities have carried out some exploration and try, in the process of university education in our country, the phenomenon of "attaching importance to cognition and despising practice, attaching importance to knowledge and despising ability" still affects the students' employment directly, the students' practical ability is not strong, but also directly affect the students' social adaptability and creativity ${ }^{[2]}$. It can be seen that the innovation and entrepreneurship education is an important measure for colleges and universities to adapt to the trend of the times and to cultivate applied and high-quality talents.

\section{Analysis on the current situation of innovation and entrepreneurship education in China}

In recent years, the difficulty of employment has become the common pressure for college students and has become the focus for social concern. Under such circumstances, self-employment oriented employment mode has become a new mode for graduates to achieve employment, innovation and entrepreneurship education has become a new direction of employment guidance. At the same time, carrying out the innovative and entrepreneurial education in colleges and universities is also the need for the adjustment of our country's economic structure and the establishment of an innovative country. Under the relevant policy support, the development of innovation and entrepreneurship education in colleges and universities has begun to take shape, but still need to work hard from guarantee system, training program, teaching staff, teaching environment and other aspects, to formulate the policy in line with the education of college students' innovation and entrepreneurship, continue to increase the investment for innovation and entrepreneurship education, 
to ensure the effectiveness of innovation and entrepreneurship education for college students, to enable students to truly achieve the combination of theory and practice and acquire scientific innovation and entrepreneurship skills under the three-in-one environment of government preferential policy, entrepreneurial opportunity and university entrepreneurship theory ${ }^{[3-4]}$. Training plan is the basis of personnel training. Innovation and entrepreneurship education can not rely solely on establishing ideas and shouting slogans, is also not only to encourage students to participate in all kinds of competitions to achieve the purpose of innovative and entrepreneurial training ${ }^{[5]}$. The school must be combined with professional features, innovative thinking will be truly integrated into the professional training programs, and training innovation ability will be carried out in the whole culture system ${ }^{[6-7]}$. Teachers are the source of development and the foundation of improvement for schools, and the teachers' team is the decisive factor of the development level for the schools. At present, many university teachers are directly engaged in the teacher industry when they graduated from graduation, and the enterprises' practical experience and work experience are insufficient ${ }^{[8]}$. Therefore, schools should often encourage teachers to use extracurricular or winter and summer vacation time to do practical exercises in enterprises, and invite business mentors or technical backbone members who have rich experience in entrepreneurial practice to undertake part of teaching contents. The teaching environment and conditions are the basis of education, both the theoretical and practical teaching links are dependent on the teaching environment and conditions.

\section{Analysis on the practice of innovation and entrepreneurship education}

The comprehensiveness and practicality of landscape architecture applied specialty are strong in Nanchang Institute of technology, the corresponding industry area is wide, and the threshold of starting a business is relatively low professional which major involved in flower art, nursery and landscape design, and has certain advantages in innovation and entrepreneurship. In recent years, the major of landscape architecture in our school conforms to the development of the times, combines with the needs of the industry, gives full play to the initiative, carrys out the management of education reform in optimizing the personnel training plan, adjusting the structure of teachers and creating a teaching environment, participating in science and technology innovation and entrepreneurship competition, etc., which lays a solid foundation for the training of landscape technology talents with the courage to innovate and start a business in the future.

\subsection{Optimizing talents training program}

Through optimizing talents training program and improving students' professional skills, the training plan has been optimized and innovated: practice teaching innovation, taking the practice teaching as an educational concept to throughout the whole teaching process. These practical teaching bodies include practical teaching activities in the teaching plan, introducing the practical teaching idea into the classroom theory teaching, a variety of participatory teaching, interactive teaching, situational teaching, discussion teaching and case teaching, etc., so as to promote a series of reform and innovation for the organization form, teaching method, teaching means of theory teaching. Innovation of training ways for applied talents, through the innovation of practice teaching ideas, system construction, platform construction, teaching staff, training base construction, management system construction of new practical teaching, in order to effectively carry out all kinds of practical teaching activities covering all aspects of teaching, and create an effective way to cultivate applied talents.

\subsection{Combination of various forms of teaching}

Through a variety of teaching methods and experience exchanges, to stimulate students' enthusiasm for self-study, and to exercise students' innovative and entrepreneurial ability. At the same time, to form a virtuous circle of mutual benefit and employment and entrepreneurship between enterprises and colleges and universities. 


\subsubsection{Professional chain link industrial chain}

Professionally and deeply integrate the design features of Jiangxi landscape planning, according to the four working processes of landscape architecture design, scheme expression, scheme deepening and project implementation, to dock the professional chain of landscape architecture from low level to advanced level, to refine the typical products, to determine the technical skills system, to construct professional foundation and guidance, taking the landscape design, engineering construction and plant landscaping as the guide, and taking the project as a carrier, to integrate the theory knowledge and technology skills as a whole, and to strengthen students' professional skills. Taking the improvement of the skills for innovation and entrepreneurship as the tongs, to carry out the "double wheel drive" talent training model. Taking the school enterprise cooperation and enterprise demonstration base and school productive training base as the building emphasis, to promote the development of innovation and entrepreneurship education andthe reform of personnel training mode for college students, and to consolidate students' innovative and entrepreneurial skills. Through the "school enterprise cooperation", we should focus on training college students' professional practical skills and improve their social employment competitiveness. We should set up the courses, such as innovative and entrepreneurial skills and so on, to improve college students' comprehensive quality of innovation and entrepreneurship.

\subsubsection{Teaching students in accordance with their aptitude and "modularization" teaching}

Through the analysis of the 300 students' learning situation in the landscape architecture of Nanchang Institute of Technology, find this major's studemts in minority, Xizang and Xinjiang have the ability to communicate with other students and teachers, and have the ability to learn theoretical knowledge of professional knowledge and practice course. Therefore, landscape architecture does not modularized teaching for professional courses, but in actual teaching process, can according to the characteristics of the minority students, to consider the difficult stratification and the difference stratification of the examination papers.

\subsubsection{Innovation and entrepreneurship and "double certificate"}

Landscape architecture is mainly for the cultivating and training the professional technical ability of landscape design, garden plant landscaping, construction drawing design, engineering construction and plant maintenance. Through the plant landscaping, combining innovation and entrepreneurship studio, to cultivate students' performance and production of micro landscape. In order to broaden student employment, set up the course of potted landscape and art flower arranging, and complete bonsai and floral works. Innovation and entrepreneurship course includes art flower arrangement, bonsai production. Innovation and entrepreneurship integrates the "double certificate", flower arranging can participate in flower competition, to train students' practical skills.

\subsection{Creating teaching conditions}

(1) The teaching demonstration base of modern garden plants in our university focuses on carrying out discipline construction, course teaching and specialty construction, and has invested millions to build experimental bases in schools. Now, the laboratory area is more than 3000 square meters, has greenhouse, bonsai production area, laboratory, cutting area and garden engineering demonstration area, has advanced experimental instruments and equipment, provided conditions for students to carry out scientific and technological innovation activities and innovation and entrepreneurship training. In addition, our school works with Jiangxi Zhong Qing Environmental Protection Engineering Co., Ltd. to establish a studio for flower and landscape and landscape design, aiming at developing students' innovative and entrepreneurial ability, improving students' professional practice and technical skills, and to achieve the deep integration of school enterprise cooperation.

(2) Setting up an out of school practice base, to improve the professional teaching practice activities for the students, the landscape architecture takes the studio and the second class as a breakthrough, takes the school enterprise cooperation, cultivating innovative applied engineering 
talents by combining production, learning and research as a goal, to establish the professional teaching method and reform ideas with "solid theoretical foundation and professional skills", and is establishing a long-term and stable cooperation between school and enterprise to cultivate the talents with more than 10 enterprises, gradually form a win-win teaching model between school and enterprise, which integrates the cooperation of teaching and research, the cooperation of production, learning and research, the training of students' practical ability, and the employment and entrepreneurship of the graduates.

\subsection{Combination of innovation and entrepreneurship}

The general situation of students' participation in science and technology innovation and entrepreneurship competition, is an important evaluation index of innovation and entrepreneurship performance, the school teachers have a profound cognition to practice teaching and innovation, through actively participate in various practical teaching activities, the second classroom and workshop, to strengthen students' innovation and entrepreneurship ability, to enhance the practice ability of students and teachers. In recent years, students majoring in landscape architecture and landscape technology, under the guidance of professional teachers in schools and mentor from enterprise, actively participate in science and technology innovation and entrepreneurship competition activities, students exercise scientific practice ability and team cooperation ability in the competition, and improve the quality of innovation and entrepreneurship, and to lay a good foundation for possible future entrepreneurial practice.

\section{Conclusions}

Formulating the training program in accordance with the specialty of landscape architecture in our school, throughout the concept of innovation and entrepreneurship education, is the basis foundation of innovation and entrepreneurship education, also conforms to the trend of social development and the trend of the times, constantly improving the level of teachers and creating teaching environment are the key measures to implement the innovation and entrepreneurship education, encouraging students to participate in various science and technology innovation and entrepreneurship competition is the effective way to motivate innovation and entrepreneurship education. The development of innovation and entrepreneurship education, need three party of government, universities, enterprises to cooperate, under the support of policy, and under the integration of school enterprise cooperation, the school can continue to develop, the cultivation of talents of applied and technical skills can be continuously improved. Taking innovation and entrepreneurship as a guide and training practical and innovative talents, the students in Nanchang Institute of technology have increasingly set up a good image of "high comprehensive quality, strong innovation spirit and outstanding practice ability", to contribute to the development of society in the future.

\section{Acknowledgements}

This work is supported by Science and technology research project of Jiangxi Provincial Education Department (GJJ151237).

\section{References}

[1] Tao Hu, Li Shen. The enlightenment of foreign innovation and entrepreneurship education model to Chinese universities [J]. Chinese university teaching, 2013 (2): 91-94.

[2] Wanguo He, Xingui Qi. The formation and its training mechanism of college students' practical ability [J]. Higher education research, 2010, (10): 62-66.

[3] Xiaodong Zhu, Yabin Zhu. The problems and countermeasures of "two abilities" education of our college students [J]. Journal of Shanxi youth cadre management institute, 2012, 25 (9): 55-57. 
[4] Baocun Liu. Establishing the concept of innovation and entrepreneurship education and cultivating innovative spirit and practical ability [J]. Chinese higher education, 2010 (12): 12-15.

[5] Fang Wang. New approach to the improvement of innovative and entrepreneurial ability for agricultural college students [J]. Laboratory science, 2011, 14 (1): 1-3.

[6] Wenjuan Chen, Guanxin Yao, Zezhong Ren. Integrating innovation and entrepreneurship education into the classroom teaching system of colleges and universities, 2012 (2): 44-45.

[7] Yongjie Wang, Guang Chen, Kaiyin Yan, etc. The practice of cultivating innovative talents through innovation and entrepreneurship class [J]. Chinese university teaching, 2011 (1): 27-29.

[8] Ping Sun, Dandan Sun. Cultivation of innovative and entrepreneurial ability for college students based on talent training model [J]. Shanxi science and technology, 2014, 29 (1): 104-106. 